\title{
A Decent Science Behind the Brahma Muhurta
}

\author{
${ }^{1}$ Dr. Rajveer Gupta,${ }^{2}$ Dr. Omhprakash Shukla,${ }^{3}$ Dr. Vivek Shrivastava , ${ }^{4}$ Dr. Pravanjan Acharya \\ ${ }^{1}$ M.D. Scholar, Department of Samhita Siddhant \\ ${ }^{2}$ M.D. Assistant professor, Department of Samhita Siddhant \\ ${ }^{3}$ M.D. Associate professor, Department of Samhita Siddhant \\ ${ }^{4}$ M.D, PhD, HOD \& Professor, Department of Samhita Siddhant, Govt.Ayurved College. Rewa (M.P)
}

\begin{abstract}
:
Ayurveda is such a holistic science that sustain the health of millions of human beings over this terra by improving the quality of standard of living and by providing curative measures for varieties of disorders. If a man follows rules described in Dincharya and Ritucharya, his longevity may be enhanced. Brahma Muhurta is a specific time that recharges biological clock in human being and maintain its rhythm and pattern day long. A biological clock or a Circadian Rhythm is any biological process that displays an endogenous, entrainable oscillation of about 24 Hours, some exogenous or external factor such as light, temperature etc. affects the circardian rythem in human called zeigeber. The deranged lifestyle also affect this clock, as a result several undesirable traits and diseases are evolved. This pre-dawn time is very useful for meditation and yogik kriyas, his smriti (memory) becomes sharp and he moves toward the ultimate goal of yoga i.e. Moksha. As per ayurvedic ideology, the Brahma Muhurta pacify the vata that certainly control the mana. Hence Brahma Muhurta is necessary for spiritual evolution. The person who wakes up early in the morning his ageing process become delayed. It is also a perfect time to align us with cosmic power as per Lok purush samya siddhanta.
\end{abstract}

Key words: Dincharya, Ritucharya, Brahma Muhurta, Biological Clock, Zeitgebers, Meditation, Yoga, Moksha, Spiritual Evolution, Ageing, Lok Purusha Samaya Siddhanta.

Introduction: Ayurveda is holistic science that sustain the health of millions of human being by narrating standard way of living and providing curative measures for several disorders. The great Indian sages told about the value of sadvrutta which keeps someone healthy with better sensorial regulation.

According to charaka one who observed these principles of sadvitta simultaneously fulfil both objectives via maintenance of positive health and control of sense faculties. [1] If a man follows the protocols mentioned in Ritucharya and Dincharya his logivity may be enhanced. The Dosha Dhatu Malakriya Samyavastha is maintained. Now a days some disease like diabetes, hypertensioin, insomnia, anxiety, depression etc. are affecting the majority of population. The root cause of these disease are deranged life style. Bad eating habit, distorted natural sleep pattern and detachment from the ancient rituals. There is inherent and inborn biological clock which regulates the daily routine activity of human being. If the deranged lifestyle affects the biological clock pattern then it may cause undesirable impact on human health. Brahma Muhurtha is a specific time that recharges the clock and maintain its rhythm and pattern day long. This ambrosial time sharpens the intellectual bytes and removes the hurdles for spirituality. So it is miraculous time for both acquiring knowledge and bonding with God via meditation and yoga practices. It also provides space for research in mantra vigyan. Acharya Charaka advised that one should take such articles which are conductive to maintenance of good health and are capable of preventing the attacks of disease. [2]

Meaning of "Brahma Muhurtha": According to Ashtang Hridaya, during the beginning of Dincharya. A healthy man should give up his bed in Brahma Muhurta to protect the Ayu. [3]

According to Arun Dutta:

The appropriate muhurta or kala to aquire the Brahma Gyan is called Brahma Muhurta. 
${ }^{1}$ Dr. Rajveer Gupta, International Journal of Ayurvedic\& Herbal Medicine 7(6) Nov.-Dec. 2017 (3005-3009)

\section{Brahma Muhurta Timing:}

Brahma Muhurta (Time of Brahma) is a period (Muhurta) one and half hour before the sun rises or more precisely 1 hours 36 minute before sun rises i.e. 96 minutes $=2$ muhurta or 4 ghatrika and muhurta lasting for 48 minutes.

According to Swami Shivanand ji- Brahma Muhurta is morning period between 3.30 A.M. and 5.30 AM. [4]

According to Religious basis of hindu belief: The last phase of night i.e. three hours before sunrises is called Brahma Muhurta. The shastra prescribed one should give up sleep at this time. [5]

According to Shankara: Brahma Muhurta time is 3 AM to 6 AM daily. It is considered to be most auspicious time when one can start/do spiritual things like observing meditation or reciting prayers or even to embark on new projects. [6]

According to Swami Gourangpada: The 48 minutes from $1 \mathrm{hrs} 36$ minute to 48 minute before sunrises. [7] There are 30 Muhurta in a day and each Muhurta posses and unique outcome or result.

\begin{tabular}{|c|c|c|c|}
\hline S.No. & Time & Name of Muhurta & RESULT \\
\hline 1. & $6: 00-6: 48$ & RUDRA & BAD \\
\hline 2. & $6: 48-7: 36$ & AHI & BAD \\
\hline 3. & $7: 36-8: 24$ & MITRA & GOOD \\
\hline 4. & $8: 24-9: 12$ & PITRU & BAD \\
\hline 5. & $9: 12-10: 00$ & VASU & GOOD \\
\hline 6. & $10: 00-10: 48$ & VARA & GOOD \\
\hline 7. & $10: 48-11: 36$ & VISVA DEVA & GOOD \\
\hline 8. & $11: 36-12: 24$ & VIDHI & GOOD \\
\hline 9. & $12: 24-13: 12$ & SATMUKHI & GOOD \\
\hline 10. & $13: 12-14: 00$ & PURUHUTA & BAD \\
\hline 11. & $14: 00-14: 48$ & BVAHINI & BAD \\
\hline 12. & $14: 48-15: 36$ & NAKTANCARA & BAD \\
\hline 13. & $15: 36-16: 24$ & VARUNA & GOOD \\
\hline 14. & $16: 24-17: 12$ & ARYAMA & GOOD \\
\hline 15. & $17: 12-18: 00$ & BHAGA & BAD \\
\hline 16. & $18: 00-18: 48$ & GRISHA & BAD \\
\hline 17. & $18: 48-19: 36$ & AJAPAD & BAD \\
\hline 18. & $19: 36-20: 24$ & AHIRBUDHNYA & GOOD \\
\hline 19. & $20: 24-21: 12$ & PUSA & GOOD \\
\hline 20. & $21: 12-22: 00$ & ASWINI & GOOD \\
\hline 21. & $22: 00-22: 48$ & YAMA & BAD \\
\hline 22. & $22: 48-23: 36$ & AGNI & BAD \\
\hline 23. & $23: 36-24: 24$ & BIDHATR & GOOD \\
\hline 24. & $24: 24-1: 12$ & CANDA & GOOD \\
\hline 25. & $1: 12-2: 00$ & ADITI & GOOD \\
\hline 26. & $2: 00-2: 48$ & JIBA & GOOD \\
\hline 27. & $2: 48-3: 36$ & VISHNU & GOOD \\
\hline 28. & $3: 38-4: 24$ & YAMIGADYUTI & GOOD \\
\hline 29. & $4: 24-5: 12$ & BRAHMA & VERY GOOD \\
\hline 30. & $5: 12-6: 00 \mathrm{AM}$ & SAMUDRAM & GOOD \\
\hline
\end{tabular}

\section{Brahma Muhurta in Ancient Classic:}

Garga Samhita 4.8.19

During ekadasi one should be pure hearted and very clean and wear clean garments, drink water only once.

Rise during Brahma Muhurta and bow down to Lord Krishna.

Garga Samhita 4.18.19 
${ }^{1}$ Dr. Rajveer Gupta, International Journal of Ayurvedic\& Herbal Medicine 7(6) Nov.-Dec. 2017 (3005-3009)

During Brahma Muhurta one should rise from from bed and mediate on godess Yamuna and at sunrises one should bath Yamuna.

Garga Samhita 8.10.7

One should rise at brahma muhurta chant the holy names of Lord Krishna and Lord Brahma and bow down before ones ganga. Only then one should place his feet on the ground. [8]

\section{Biological circadian rhythm and Brahma Muhurta:}

Brahma Muhurta is very crucial time which switches biological clock every day and reboot and regulate the rhythm and pattern of biological clock.

A circardian rhythm is any biological process that displays an endogenous oscillation of about 24 hours.

These 24 hour rhythm driven by a circadian clock. and they have been widely observed in plant, animal and fungi etc.

The term circadian derived from the latin word 'Circa' meaning "Around" (or approximately) and "diem" meaning is "day".

Although the circardian rhythms are endogenous ("built in" self sustained) they are adjusted (entrained) to the local environment by external causes called zeitgebers ("time giver") which include light temperature and redox cycle.

Criteria for Circadian Rhythm: To be called circadian, a biological rhythm must meet three general criteria.

1. The rhythm has an endogenous free running period that lasts approximately 24 hours. The rhythm persist in constant condition (i.e. constant darkness) with a period of about 24 hours.

2. The rhythms are entrainable. The rhythm can be reset by exposure to external stimuli (such as light and heat etc.), a process called entrainment. The external stimulus used to entrain a rhythm a rhythm is called the Zeitgeber or time given travel across the time zone illustrates the ability of human biological clock to adjust to the local time.

3. The rhythm exhibit temperature compensation, in other words, they maintain circadian rhythm or periodicity over a range of physiological temperature and differences in thermal energy will affects the kinetics of all molecular process in their cell.

- Circadian rhythm allow organism to anticipate and prepare for precise and regular environmental changes. They thus enable organism to best capitalize on environmental resources (e.g. food and light) compared to those that can not predict such availability. It has therefore been suggested that circadian rhythm put organism at a selective advantage in evolutionary terms. It is also important in regulatory and coordinating internal metabolic process as in coordinating with the environment.

- What above the circadian rhythm to evolve has been an enigmatic question. Previous hypothesis emphasized that photo sensitive proteins and circardian rhythem may have originated together.

\section{Biological Clock in Human:}

A variation of an eskinogram illustrating the influence of light and darkness on circadian rhythm and related physiology and behaviour through the Supra Chiasmatic Nucleus (SCN), a pair of distinct groups of cells located in the hypothalamus. Destruction SCN results in complete absence of a regular sleep wake rhythm. The SCN receives information about illumination through the eyes contains classical photoreceptor (rods and cones) which are used for conventional vision, but the retina also contains specialized ganglion cell that are photosensitive and project directly to the $\mathrm{SCN}$, where they help in the entrainment (Synchronization) of this master circadian clock. These cells contains the photopigment milanopsin and their signals follow a pathway called retinohypothalmic tract leading to SCN. If cells from the SCN are removed and cultured they maintain their own rhythm in the absence of external cues. The SCN takes the information on the lengths of the day and night from the retina, interprets it and passes it on to the Peneal gland, a tiny structure shaped like a pin cone and located on

epithalmous. Secretion of melatonin peaks at night and ebbs during the day and its presence provides information about the night length. [9] 
${ }^{1}$ Dr. Rajveer Gupta, International Journal of Ayurvedic\& Herbal Medicine 7(6) Nov.-Dec. 2017 (3005-3009)

\section{Characteristics of Brahma Muhurta:}

\section{Get Spritual goals into focus: Go Deeper.}

Waking up early can help bring higher life goals immediately into focus for whole day. It is mostly effective way to get serious about spiritual evolution. It is understood by Yogis that the mind is repository of different impression and memories known in Sanskrit as sanskar. These impression in our mind give rise to our various desires. As well all know, Desire is the main driving force behind all actions. After waking up early particularly in Brahma Muhurta and taking proper bath, one can immediately begin to chant sacred mantras and start the process of re-spritualizing the mind.

-As per Ayurveda, for a better health one should wake up in Brahma Muhurta. In $8^{\text {th }}$ chapter of Vimana Sthana while elaborating characters of shishya (scholar) charak stated that the disciple should be healthy and soley devoted to study. He should get up early in the morning or in the last quarter of night. [10]

-The science behind all that is some elements like ozone help in brain stimulation and endorphin concentration is at peak which energises the fabrics of brain and stabilize the mind or mana.

-Brahma Muhurta is an excellent period for spiritual practices and has sacred energy for worship of Brahma inside you.

-This time is very important as most of the people are asleep and the even the animals are sleeping. Meditation is a coherent flow of energy and is distributed by the external atmosphere and other people's vibrations and thought forms. These things do not affects meditator during Brahma Muhurta. [11]

-The atmosphere is not polluted by the radiations of worldly feelings. At that time devotees awake and pray god. Their pure mental rays pervade all over the world. Thus it becomes congenital and encouraging atmosphere. Nothing is stirring at this time and things are in state of positive high potential as the sunrises. When the Sun begin its journey over the head, it tends to shift our mental energy to a more externally oriented working state, in which it becomes harder to concentrate more internally and more deeper.

According to Acharya Charak: Recurrence of all sensation is checked through yoga and moksha. The absolute eradication of sensation is attained through moksha. The yoga is a means to attain the moksha. [12] Keep your life style into balance- Get Shakti

Ancient Classical believe that by getting up early in the morning man gains beauty, praise intelligence, money, health and long age and his life become beautiful like lotus. [13]

There is something to be said about hormony and balance we feel when aligning our sleep cycle with the natural pattern and the movements of nature. "Early to bed, early to rise" is an old adage in reference to this point. Far to often, in changing our passion, we slip into highly unregulated life style, in which we sleep in random time and so on. The disturbed life style upsets the biological clock, as a result various problems like diabetes, obesity, Insomnia etc are evolved. So we should have a set schedule in general which is not only good for the functioning of bodily rhythm, but good for the mind as well. The mind will know when it is time to flow into different activities, thus ultimately helping us to become more productive. The life style of someone's has direct or indirect effect on "Dhatusamyavasta" (tissue equilibrium status). If our life style is synchronised with biological clock, then we retain our healthy state for lifelong. Charak has stated that "In the present context the effect is equilibrium of the present context, the object of the science is maintained of equlillibrium of tissue. [14]

The person who get up early in morning his ageing process become delayed as it decreases oxidative stress in body.

\section{Universal Influence- Align with cosmic power.}

Yogis believe that our environment influences our behaviour in subtle way according to quality of people, places, food and the time of the day we most associated with. In vedic stories it is stated that those who are inclined to demonic nature, or the "Dark side" feed off the energy of night. Consequently many crimes are commited in the dead of night. The night is often associated with drunkness, loneliness etc. whereas the morning environment is notably a time of peace and serenity. It is understood that quality of morning environment can actually influences similar characteristics within our mind and behaviour. [15]

\section{Conclusion:}

Brahma Muhurta is a very useful time in 24 Hour cycle of a day. It enhances the intellectual property of human being because variety of compatible biological event that nurtures the neurons and every vital organs 
${ }^{1}$ Dr. Rajveer Gupta, International Journal of Ayurvedic\& Herbal Medicine 7(6) Nov.-Dec. 2017 (3005-3009)

of the body, takes place in positive way. It regulates the unstability of mind thus very important for yogik practices. If someone synchronize life style with biological clock, his health would be preserved against various disorders. In short we can say that Brahma Muhurta is an auspicious time that promotes physical, mental, social and spiritual health as well.

\section{References:}

1. Dr. Ram Karan Sharma and Vaidya Bhagwan Das, Charak samhita Vol. I (Ch. Su. 8/18) page 17, Chaukhambha Sanskrit series Varanasi 2014.

2. Dr. Ram Karan Sharma and Vaidya Bhagwan Das, Charak Samhita Vol I (Ch. Su. 1/53) page 39, Choukhambha Sanskrit series Varanasi 2014

3. Dr. Banwari Lal Gour, Ashtanga Hridayam Samvartika Commentory (As. H.54 2/2) page no. 19, chaukhambha orientaliya Varanasi 2013

4. Dr. claudiaweltch.com

5. Bhojraj Dwivedi, Religious basis of hindu beliefs page 25, Diamond Poket Book Jodhpur 2006

6. Vandeguruparamparaam. blogspot.com

7. Nittai.ved. hyf

8. (I,II,III) Nitaiveda.com

9. En.wikipedia.org

10. Dr. Ramkaran Sharma and Vaidya Bhagwan Das, Charak Samhita Vol II (ch. Vi 8/9) pg 220, chaukhambha Sanskrit series Varanasi 2014

11. Vedguru paramparram.blogspot.com

12. Vaidya Harischandra singh Kushwaha, Charak Samhita, Ayurved Deepika's Ayushi commentary (ch.sha. 1/137), page no. 743 chaukhamba Orientalia Varanasi 2011

13. Dr. Ramkaran Sharma and Vaidya bhagwan Das, Charak Samhita vol I page 39, Chaukhamba Orientalia Varanasi 2014

14. Bhojraj Dwivedi, Religious basis of Hindu beliefs page 25, Diamond Pocket book Jodhpur 2006

15. Www. 16rounds.com 